\title{
COMPARATIVE MACROSCOPIC STUDY OF OSTEOCHONDRAL DEFECTS PRODUCED IN FEMURS OF RABBITS REPAIRED WITH BIOPOLYMER GEL CANE SUGAR
}

Paulo Cezar Vidal Carneiro de Albuquerque ${ }^{1}$, Saulo Monteiro dos Santos ${ }^{1}$, José Lamartine de Andrade Aguiar ${ }^{1}$, Nicodemus Pontes Filho², Roberto José Vieira de Mello², Mariana lúcia Correia Ramos Costa ${ }^{2}$, Clarissa Miranda Carneiro de Albuquerque Olbertz ${ }^{3}$, Tarciana Mendonça de Souza Almeida $^{3}$, Alessandro Henrique da Silva Santos ${ }^{4}$, Joacil Carlos da Silva 5

\section{ABSTRACT}

Objective: To study the surface, coloring, consistency, continuity and healing of osteochondral defects produced in the femoral condyles of rabbits and filled with sugar cane biopolymer gel (SCBG), after 90, 120 and 180 days, and in comparison with a control group. Method: Sixteen adult New Zealand white rabbits aged 6 to 7 months, weighing between 2 and $2.5 \mathrm{~kg}$ and without locomotor system abnormalities were studied. In all the animals, a defect was made in the femoral condyles of the right and left knees, measuring $3.2 \mathrm{~mm}$ in diameter and $4 \mathrm{~mm}$ in depth, using a trephine. The animals were divided into two groups: study group formed by the right knees, in which the medial and lateral condyles received implants of SCBG; and control group formed by the left knees, in which the medial and lateral condyles were allowed to heal naturally. The knees were assessed 90, 120 and 180 days after the operation. After the animals had been sacrificed, the anatomical specimens were resected and placed in Bouin's solution. They were then photographed with a Nikon Coolpix $5400^{\circledR}$ coupled to a Nikon SM2800 ${ }^{\circledR}$ stereoscopic loupe, to analyze the surface, coloring, consistency, continuity and healing. Results: The results were evaluated using the chi-square test. There were no significant differences in the macroscopic assessments of healing between the study and control groups. Conclusion: With regard to the surface, coloring, consistency, continuity and healing of the defects, the macroscopic appearance of the tissue repaired with SCBG was similar to that of the control group.

Keywords - Polymers; Sugar; Wound Healing; Cartilage, Articular; Rabbits

\section{INTRODUCTION}

Osteochondral defects generally evolve into degenerative joint disease, characterized by pain, stiffness and loss of joint mobility. This condition is among the commonest causes of pain and incapacity among the middle-aged and elderly population. Because joint cartilage does not have vascularization, its healing potential is limited and, consequently, treating cartilage continues to be a veritable challenge for orthopedists ${ }^{(1-4)}$.
The healing process for cartilage does not follow the natural progression of necrosis, inflammation and repair. Because chondrocytes are not vascularized, they do not form hematomas, fibrins or coagulum when injured, and they serve only as a framework for new repair tissue. The absence of a vascular phase limits the number of cells available for an inflammatory response to the trauma ${ }^{(1,3-8)}$.

Among the treatments for repairing osteochondral defects, debridement of the injured cartilage,

\footnotetext{
$1-\mathrm{PhD}$. Professor in the Department of Surgery, Federal University of Pernambuco, Recife, PE, Brazil.

2 - Professor in the Department of Pathology, Federal University of Pernambuco, Recife, PE, Brazil.

3 - Medical Student at the Federal University of Pernambuco, Recife, PE, Brazil.

4 - Assistant Professor in the Department of Accounting and Actuarial Sciences, Federal University of Pernambuco, Recife, PE, Brazil.

5 - Neurosurgeon at Hospital das Clínicas, Federal University of Pernambuco, Recife, PE, Brazil.

Work performed in the Experimental Surgery Group, Department of Surgery, Federal University of Pernambuco.

Correspondence: Av. Prof. Moraes Rêgo s/n, Cidade Universitária, 50670-420 Recife, PE. E-mail: paulovidal_@hotmail.com

Work received for publication: January 29, 2011; accepted for publication: March 23, 2011.
} 
perforation of the subchondral bone plate and transplantation of chondral or osteochondral tissue can be highlighted. The biological methods of implantation of cultures of potentially chondrogenic cells, mesenchymal chondrocytes and cells, cultured autologous chondrocytes and osteochondral autologous grafts can also be used ${ }^{(4,7,9-17)}$.

These techniques are very costly, and the difficulties thus imposed have led to a search for alternatives ${ }^{(4,13-17)}$.

Sugarcane biopolymer is a natural exopolysaccharide obtained through the action of bacteria of the species Zoogloea sp, with culturing in sugarcane molasses, and its chemical structure is composed of different monosaccharides: glucose $87.57 \%$, xylose $8.58 \%$, ribose $1.68 \%$, glucuronic acid $0.83 \%$, mannose $0.82 \%$, arabinose $0.37 \%$, galactose $0.13 \%$, rhamnose $0.01 \%$ and fucose $0.01 \%$. It currently forms an official line of research within the Postgraduate Program on Surgery at the Federal University of Pernambuco (UFPE). It has been used in different animal models and in different tissue bodies, with the aim of providing repair, replacement or support. These studies have shown that it has low toxicity, high osteoconductivity, low production cost, biocompatibility and high integrative power in relation to different living tissues. These characteristics indicate that this product would be very competitive in relation to similar imported synthetic products ${ }^{(17-23)}$. Based on these results, the biopolymer in gel form (which facilitates its application for filling cavities) could be used on its own or in association with factors that induce healing, for treating osteochondral defects or critical lesions. The aim of this study was to evaluate the surface, coloring, continuity, consistency and healing of osteochondral defects that had been produced in rabbit femoral condyles and were filled with sugarcane biopolymer gel (SCBG), after 90, 120 and 180 days, in comparison with a control group.

\section{METHODS}

A controlled experimental study was conducted using 16 young adult New Zealand White rabbits, aged six or seven months and weighing between 2 and 2.5 $\mathrm{kg}$, without abnormalities of the locomotor system. They came from the vivarium of the Experimental
Surgery Center, Federal University of Pernambuco. The procedures were carried out under veterinary supervision and were approved by the Ethics Committee for Animal Experimentation of the Biological Sciences Center, Federal University of Pernambuco (CEEAUFPE). The animals were confined in metal cages but could walk freely, and were fed with standard pelletized feed and water ad libitum.

\section{Surgical technique}

The rabbits were subjected to general anesthesia consisting of 5\% ketamine hydrochloride at a dose of $50 \mathrm{mg} / \mathrm{kg}$ of weight, in association with $10 \%$ chloral hydrate at a dose of $0.5 \mathrm{ml} / \mathrm{kg}$ of weight, and this was complemented with local anesthesia consisting of $5 \mathrm{ml}$ of $2 \%$ xylocaine, diluted in $9 \mathrm{ml}$ of distilled water. After the surgical area had been shaved and antisepsis had been applied, a medial parapatellar incision was made, followed by arthrotomy and lateral dislocation of the patella to enable better viewing. With the knee flexed, each femoral condyle was exposed and, with the aid of a metal trephine, osteochondral defects measuring $3.2 \mathrm{~mm}$ in diameter and $4.0 \mathrm{~mm}$ in depth were produced in the femoral condyles of each knee. The animals were divided into two groups: the study group, consisting of the right knees, in which the medial and lateral condyles were filled with SCBG, using an insulin syringe to inject the gel into the defects; and the control group, consisting of the left knees, in which the defects in the medial and lateral condyles were left unfilled. The rabbits were sacrificed as follows: 90 days after the surgical procedure (six rabbits), 120 days (five rabbits) and 180 days (five rabbits). Subsequently, the anatomical specimens were resected and immersed in Bouin's solution, with the aim of then conducting a macroscopic evaluation (Figure $1 \mathrm{~A}-\mathrm{H}$ ).

\section{Macroscopic evaluation}

The assessment criterion used for comparative study on the osteochondral defects produced in the rabbit knees was macroscopic inspection, as proposed by Ribeiro et $a l^{(7)}$, using the following qualitative parameters: surface, coloration, consistency, continuity and healing of the defect.

Joint surface - classified as planar, uneven or irregular; 

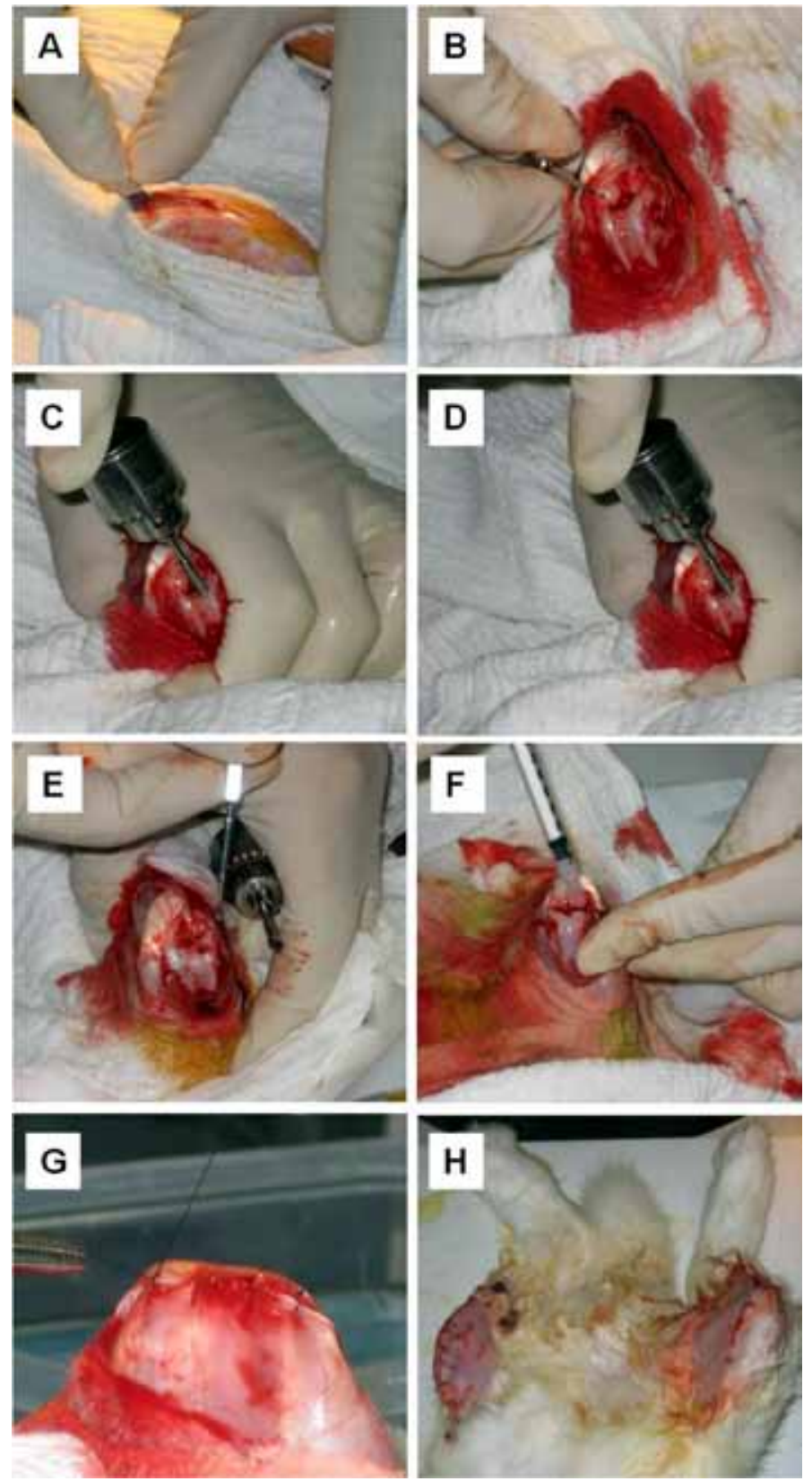

Figure 1 - (A) Operative incision; (B) Dislocation of patella; (C, D and E) Production of defects using trephine; (F) Filling of defects using sugarcane biopolymer gel; ( $G$ and $H)$ Suturing of the skin.

Coloration - classified as translucent when the natural color of the cartilage was seen; opaque when the color was natural but without shine; or discolored when the color was not natural;

Consistency of the repair - classified as firm or softened; Continuity - assessment of the leveling and integration of the repair with the adjacent cartilage; classified as less than $50 \%$ if there was no integration; between 50 and $75 \%$ if there was partial integration of the defect; and greater than $75 \%$ if there was full integration of the defect with the cartilage surface.
Healing of the defect - this related to filling of the entire lesion with healing tissue and was classified as total, when the defect was completely healed, or partial, divided into four categories: greater than or equal to $75 \%$; less than $75 \%$ and greater than or equal to $50 \%$; less than $50 \%$ and greater than or equal to $25 \%$; less than $25 \%$ and down to $0 \%$.

For the inspections, two simultaneous evaluators were used, who agreed about the evaluations of each quality observed. To classify the osteochondral defects, a Nikon SM2800 ${ }^{\circledR}$ stereoscopic microscope was used, coupled to a Nikon Coolpix $5400^{\circledR}$ camera, which were made available by the Department of Morphology of the Aggeu Magalhães Laboratory, Recife, PE.

In the statistical analysis, absolute and relative frequency distributions were obtained, and the chi-square test was used to investigate whether there was homogeneity of distribution between the two groups. The data were input to the Excel spreadsheet and were analyzed using the GraphPad Prism statistical software, version 4.0. The significance level was taken to be $5 \%(\mathrm{p}<0.05)$.

\section{RESULTS}

The results from the dependent variables proposed for the different groups of animals are in Tables 1, 2, 3 and 4 .

For the rabbits sacrificed after 90 days, application of the chi-square test to investigate the homogeneity of frequency distribution in the study and control group, according to qualitative evaluation of the lateral and medial condyles in relation to the variables of surface, coloration, consistency, continuity and healing of the defect, produced the following results for the lateral condyle: $p=0.1767, p=0.2636, p=1.000^{*}, p=$ 0.2899 and $p=0.1342 *$, respectively; and for the medial condyle: $\mathrm{p}=0.3998, \mathrm{p}=0.7881, \mathrm{p}=1.000^{*}$, $\mathrm{p}=0.3012$ and $\mathrm{p}=1.000^{*}$, respectively (Table 1$)$.

For the rabbits sacrificed after 120 days, application of the chi-square test to investigate the homogeneity of frequency distribution in the study and control group, according to qualitative evaluation of the lateral and medial condyles in relation to the variables of surface, coloration, 
Table 1 - Frequency distribution of the variables of surface, coloration, consistency, continuity and healing of the defect in animals sacrificed 90 days after the surgical procedure.

Rabbits: 6/7/8/13/19/22

\begin{tabular}{|c|c|c|c|c|c|c|c|c|}
\hline & \multicolumn{8}{|c|}{ Groups } \\
\hline & \multicolumn{4}{|c|}{ Study } & \multicolumn{4}{|c|}{ Control } \\
\hline \multirow[t]{3}{*}{ Parameters } & \multicolumn{4}{|c|}{ Condyles (right knee) } & \multicolumn{4}{|c|}{ Condyles (left knee) } \\
\hline & \multicolumn{2}{|c|}{ Condyles } & \multicolumn{2}{|c|}{ medial } & \multicolumn{2}{|c|}{ lateral } & \multicolumn{2}{|c|}{ medial } \\
\hline & $\mathrm{n}$ & $\%$ & $\mathrm{n}$ & $\%$ & $\mathrm{n}$ & $\%$ & $\mathrm{n}$ & $\%$ \\
\hline \multicolumn{9}{|l|}{ Surface } \\
\hline Planar & 4 & 66.7 & 5 & 83.3 & 1 & 16.7 & 3 & 50.0 \\
\hline Uneven & 2 & 33.3 & 1 & 16.7 & 4 & 66.6 & 2 & 33.3 \\
\hline Irregular & 0 & 0.0 & 0 & 0.0 & 1 & 16.7 & 1 & 16.7 \\
\hline \multicolumn{9}{|l|}{ Coloration } \\
\hline & 0 & 0,0 & 1 & 16,7 & 2 & 33,3 & 2 & 33,3 \\
\hline Translucent & 0 & 0.0 & 1 & 16.7 & 2 & 33.3 & 2 & 33.3 \\
\hline Opaque & 2 & 33.3 & 1 & 16.7 & 2 & 33.3 & 1 & 16.7 \\
\hline Discolored & 4 & 66.7 & 4 & 66.6 & 2 & 33.3 & 3 & 50.0 \\
\hline \multicolumn{9}{|l|}{ Consistency } \\
\hline & 0 & 0,0 & 0 & 0,0 & 0 & 0,0 & 0 & 0,0 \\
\hline Firm & 6 & 100.0 & 6 & 100.0 & 6 & 100.0 & 6 & 100.0 \\
\hline Not firm & 0 & 0.0 & 0 & 0.0 & 0 & 0.0 & 0 & 0.0 \\
\hline \multicolumn{9}{|l|}{ Continuity } \\
\hline & 0 & 0,0 & 0 & 0,0 & 2 & 33,3 & 2 & 33,3 \\
\hline \multicolumn{9}{|l|}{ None } \\
\hline$(<50 \%)$ & 2 & 33.3 & 3 & 50.0 & 1 & 16.7 & 2 & 33.3 \\
\hline Partial & 0 & 0,0 & 0 & 0,0 & 0 & 0,0 & 0 & 0,0 \\
\hline$(\leq 50 \geq 75 \%)$ & 4 & 66.7 & 3 & 50.0 & 3 & 50.0 & 2 & 33.3 \\
\hline Total $(<75 \%)$ & 0 & 0.0 & 0 & 0.0 & 2 & 33.3 & 2 & 33.3 \\
\hline \multicolumn{9}{|l|}{ Healing of the defect } \\
\hline Total & 3 & 50.0 & 2 & 33.3 & 1 & 16.7 & 3 & 50.0 \\
\hline Partial & 0 & 0.0 & 0 & 0.0 & 0 & 0.0 & 0 & 0.0 \\
\hline$<100 \% \geq 75 \%$ & 1 & 16.7 & 2 & 33.3 & 1 & 16.7 & 1 & 16.7 \\
\hline$<75 \% \geq 50 \%$ & 0 & 0.0 & 1 & 16.7 & 3 & 49.9 & 2 & 33.3 \\
\hline$<50 \% \geq 25 \%$ & 0 & 0.0 & 0 & 0.0 & 1 & 16.7 & 0 & 0.0 \\
\hline$<25 \%$ to $0 \%$ & 2 & 33.3 & 1 & 16.7 & 0 & 0.0 & 0 & 0.0 \\
\hline
\end{tabular}

consistency, continuity and healing of the defect, produced the following results for the lateral condyle: $\mathrm{p}=1.000^{*}, \mathrm{p}=1.000^{*}, \mathrm{p}=1.000^{*}, \mathrm{p}=0.5238$ and $\mathrm{p}$ $=0.1429^{*}$, respectively; and for the medial condyle: $\mathrm{p}=1.000^{*}, \mathrm{p}=1.000^{*}, \mathrm{p}=1.000^{*}, \mathrm{p}=0.4444$ and $\mathrm{p}$ $=1.000^{*}$, respectively (Table 2 ).

For the rabbits sacrificed after 180 days, application of the chi-square test to investigate the homogeneity of frequency distribution in the study and control group, according to qualitative evaluation of the lateral and medial condyles in relation to the variables of surface, coloration, consistency, continuity and healing of the defect, produced the following results for the lateral condyle: $\mathrm{p}=1.000^{*}, \mathrm{p}=0.3678, \mathrm{p}=1.000^{*}, \mathrm{p}=$ 0.3678 and $p=1.000 *$, respectively; and for the medial condyle: $\mathrm{p}=0.2635, \mathrm{p}=0.4444^{*}, \mathrm{p}=1.000^{*}, \mathrm{p}=$ 0.2635 and $p=0.1667^{*}$, respectively (Table 3 ).

For all the three groups analyzed, application of the chi-square test to investigate the homogeneity of frequency distribution in the study and control group, according to qualitative evaluation of the lateral and medial condyles in relation to the variables of surface, coloration, consistency, continuity and healing of the defect, produced the following results for the lateral condyle: $p=0.722, p=0.430, p=1.000 *, p=1.000 *$ and $\mathrm{p}=0.0518^{*}$, respectively; and for the medial condyle: $\mathrm{p}=1.000^{*}, \mathrm{p}=0.551, \mathrm{p}=1.000^{*}, \mathrm{p}=$ $0.279^{*}$ and $\mathrm{p}=0.190$, respectively (Table 4).

The result from the statistical test used to investigate the frequency differences found in the different groups did not reject the nullity hypothesis between the variables.

Photographs of the right knee (study group) and left knee (control group) in one rabbit from each sacrifice group can be seen in Figures 2A - F.

\section{DISCUSSION}

In the model used, rabbits were chosen as the experimentation animal because this is the species most commonly used for repairs of osteochondral defects ${ }^{(1,7)}$.

It was decided to use a trephine to produce the defects because this made it possible to create uniform defects. This tool os frequently used in studies on the healing of osteochondral lesions ${ }^{(13-17)}$. Regarding the dimensions of the defect produced, we chose to use 
Table 2 - Frequency distribution of the variables of surface, coloration, consisten cy, continuity and healing of the defect in animals sacrificed 120 days after the surgical procedure.

\section{Rabbits: $1 / 2 / 3 / 4 / 5$}

\begin{tabular}{|c|c|c|c|c|c|c|c|c|}
\hline & \multicolumn{8}{|c|}{ Groups } \\
\hline & \multicolumn{4}{|c|}{ Study } & \multicolumn{4}{|c|}{ Controle } \\
\hline & \multicolumn{4}{|c|}{$\begin{array}{l}\text { Condyles } \\
\text { (right knee) }\end{array}$} & \multicolumn{4}{|c|}{$\begin{array}{l}\text { Condyles } \\
\text { (left knee) }\end{array}$} \\
\hline \multirow[t]{2}{*}{ Parameters } & \multicolumn{2}{|c|}{ lateral } & \multicolumn{2}{|c|}{ medial } & \multicolumn{2}{|c|}{ lateral } & \multicolumn{2}{|c|}{ medial } \\
\hline & $\mathrm{n}$ & $\%$ & $\mathrm{n}$ & $\%$ & $\mathrm{n}$ & $\%$ & $\mathrm{n}$ & $\%$ \\
\hline \multicolumn{9}{|l|}{ Surface } \\
\hline Planar & 3 & 60.0 & 3 & 60.0 & 3 & 60.0 & 3 & 60.0 \\
\hline Uneven & 2 & 40.0 & 2 & 40.0 & 2 & 40.0 & 2 & 40.0 \\
\hline Irregular & 0 & 0.0 & 0 & 0.0 & 0 & 0.0 & 0 & 0.0 \\
\hline \multicolumn{9}{|l|}{ Coloration } \\
\hline Translucent & 2 & 40.0 & 2 & 40.0 & 2 & 40.0 & 2 & 40.0 \\
\hline Opaque & 0 & 0.0 & 0 & 0.0 & 0 & 0.0 & 0 & 0.0 \\
\hline Discolored & 3 & 60.0 & 3 & 60.0 & 3 & 60.0 & 3 & 60.0 \\
\hline \multicolumn{9}{|l|}{ Consistency } \\
\hline Firm & 5 & 100.0 & 5 & 100.0 & 5 & 100.0 & 5 & 100.0 \\
\hline Not firm & 0 & 0.0 & 0 & 0 & 0 & 0.0 & 0 & 0.0 \\
\hline \multicolumn{9}{|l|}{ Continuity } \\
\hline None & 3 & 60,0 & 0 & 0,0 & 1 & 20,0 & 2 & 40,0 \\
\hline$(<50 \%)$ & 3 & 60.0 & 0 & 0.0 & 1 & 20.0 & 2 & 40.0 \\
\hline Partial & 0 & 0,0 & 0 & 0,0 & 0 & 0,0 & 0 & 0,0 \\
\hline$(\leq 50 \geq 75 \%)$ & 2 & 40.0 & 5 & 100.0 & 4 & 80.0 & 3 & 60.0 \\
\hline Total $(<75 \%)$ & 0 & 0.0 & 0 & 0.0 & 0 & 0.0 & 0 & 0.0 \\
\hline \multicolumn{9}{|l|}{ Healing of the defect } \\
\hline Total & 3 & 60.0 & 1 & 20.0 & 1 & 20.0 & 2 & 40.0 \\
\hline Partial & 0 & 0.0 & 0 & 0.0 & 0 & 0.0 & 0 & 0.0 \\
\hline$<100 \% \geq 75 \%$ & 0 & 0.0 & 2 & 40.0 & 2 & 40.0 & 1 & 20.0 \\
\hline$<75 \% \geq 50 \%$ & 0 & 0.0 & 1 & 20.0 & 2 & 40.0 & 1 & 20.0 \\
\hline$<50 \% \geq 25 \%$ & 0 & 0.0 & 1 & 20.0 & 0 & 0.0 & 1 & 20.0 \\
\hline$<25 \%$ to $0 \%$ & 2 & 40.0 & 0 & 0.0 & 0 & 0.0 & 0 & 0.0 \\
\hline
\end{tabular}

Table 3 - Frequency distribution of the variables of surface, coloration, consistency, continuity and healing of the defect in animals sacrificed 180 days after the surgical procedure.

\begin{tabular}{|c|c|c|c|c|c|c|c|c|}
\hline \multicolumn{9}{|c|}{ Rabbits: $23 / 26 / 27 / 30 / 32$} \\
\hline & \multicolumn{8}{|c|}{ Groups } \\
\hline & \multicolumn{4}{|c|}{ Study } & \multicolumn{4}{|c|}{ Control } \\
\hline & \multicolumn{4}{|c|}{$\begin{array}{l}\text { Condyles } \\
\text { (right knee) }\end{array}$} & \multicolumn{4}{|c|}{$\begin{array}{l}\text { Condyles } \\
\text { (left knee) }\end{array}$} \\
\hline \multirow[t]{2}{*}{ Parameters } & \multicolumn{2}{|c|}{ lateral } & \multicolumn{2}{|c|}{ medial } & \multicolumn{2}{|c|}{ lateral } & \multicolumn{2}{|c|}{ medial } \\
\hline & $\mathrm{n}$ & $\%$ & $\mathrm{n}$ & $\%$ & $\mathrm{n}$ & $\%$ & $\mathrm{n}$ & $\%$ \\
\hline \multicolumn{9}{|l|}{ Surface } \\
\hline Planar & 3 & 60.0 & 2 & 40.0 & 4 & 80.0 & 4 & 80.0 \\
\hline Uneven & 2 & 40.0 & 1 & 20.0 & 1 & 20.0 & 1 & 20.0 \\
\hline Irregular & 0 & 0.0 & 2 & 40.0 & 0 & 0.0 & 0 & 0.0 \\
\hline \multicolumn{9}{|l|}{ Coloration } \\
\hline Translucent & 0 & 0.0 & 0 & 0.0 & 1 & 20.0 & 0 & 0.0 \\
\hline Opaque & 1 & 20.0 & 2 & 40.0 & 0 & 0.0 & 0 & 0.0 \\
\hline Discolored & 4 & 80.0 & 3 & 60.0 & 4 & 80.0 & 5 & 100.0 \\
\hline \multicolumn{9}{|l|}{ Consistency } \\
\hline Firm & 5 & 100.0 & 4 & 80.0 & 5 & 100.0 & 5 & 100.0 \\
\hline Not firm & 0 & 0.0 & 1 & 20.0 & 0 & 0.0 & 0 & 0.0 \\
\hline \multicolumn{9}{|l|}{ Continuity } \\
\hline None & 2 & 40,0 & 2 & 40,0 & 4 & 80,0 & 4 & 80,0 \\
\hline$(<50 \%)$ & 2 & 40.0 & 2 & 40.0 & 4 & 80.0 & 4 & 80.0 \\
\hline Partial & 1 & 20,0 & 1 & 20,0 & 0 & 0,0 & 1 & 20,0 \\
\hline$(\leq 50 \geq 75 \%)$ & 2 & 40.0 & 2 & 40.0 & 1 & 20.0 & 0 & 0.0 \\
\hline Total $(<75 \%)$ & 1 & 20.0 & 1 & 20.0 & 0 & 0.0 & 1 & 20.0 \\
\hline \multicolumn{9}{|l|}{$\begin{array}{l}\text { Healing of the } \\
\text { defect }\end{array}$} \\
\hline Total & 3 & 60.0 & 2 & 40.0 & 4 & 80.0 & 4 & 80.0 \\
\hline Partial & 0 & 0.0 & 0 & 0.0 & 0 & 0.0 & 0 & 0.0 \\
\hline $\begin{array}{c}<100 \% \geq \\
75 \%\end{array}$ & 1 & 20.0 & 0 & 0.0 & 0 & 0.0 & 0 & 0.0 \\
\hline$<75 \% \geq 50 \%$ & 1 & 20.0 & 0 & 0.0 & 0 & 0.0 & 0 & 0.0 \\
\hline$<50 \% \geq 25 \%$ & 0 & 0.0 & 0 & 0.0 & 1 & 20.0 & 1 & 20.0 \\
\hline$<25 \%$ to $0 \%$ & 0 & 0.0 & 3 & 60.0 & 0 & 0.0 & 0 & 0.0 \\
\hline
\end{tabular}


Table 4 - Frequency distribution of the variables of surface, coloration, consistency, continuity and healing of the defect in all the animals sacrificed in all the groups.

Total of 16 samples: $90 / 120 / 180$ days

\begin{tabular}{|c|c|c|c|c|c|c|c|c|}
\hline & \multicolumn{8}{|c|}{ Groups } \\
\hline & \multicolumn{4}{|c|}{ Study } & \multicolumn{4}{|c|}{ Control } \\
\hline & \multicolumn{4}{|c|}{$\begin{array}{l}\text { Condyles } \\
\text { (right knee) }\end{array}$} & \multicolumn{4}{|c|}{$\begin{array}{l}\text { Condyles } \\
\text { (left knee) }\end{array}$} \\
\hline \multirow[t]{2}{*}{ Parameters } & \multicolumn{2}{|c|}{ lateral } & \multicolumn{2}{|c|}{ medial } & \multicolumn{2}{|c|}{ lateral } & \multicolumn{2}{|c|}{ medial } \\
\hline & $\mathrm{n}$ & $\%$ & $\mathrm{n}$ & $\%$ & $\mathrm{n}$ & $\%$ & $\mathrm{n}$ & $\%$ \\
\hline \multicolumn{9}{|l|}{ Surface } \\
\hline Planar & 10 & 62.5 & 10 & 62.5 & 8 & 50.0 & 10 & 62.5 \\
\hline Uneven & 6 & 37.5 & 4 & 25.0 & 7 & 43.8 & 5 & 31.3 \\
\hline Irregular & 0 & 0.0 & 2 & 12.5 & 1 & 6.2 & 1 & 6.2 \\
\hline \multicolumn{9}{|l|}{ Coloration } \\
\hline Translucent & 2 & 12.5 & 3 & 18.8 & 5 & 31.3 & 4 & 25.0 \\
\hline Opaque & 3 & 18.8 & 3 & 18.8 & 2 & 12.5 & 1 & 6.2 \\
\hline Discolored & 11 & 68.8 & 10 & 62.4 & 9 & 56.3 & 11 & 68.8 \\
\hline \multicolumn{9}{|l|}{ Consistency } \\
\hline Firm & 16 & 100.0 & 15 & 93.8 & 16 & 100.0 & 16 & 100 \\
\hline Not firm & 0 & 0.0 & 1 & 6.2 & 0 & 0.0 & 0 & 0.0 \\
\hline \multicolumn{9}{|l|}{ Continuity } \\
\hline None & 8 & 50,0 & 10 & 62,3 & 8 & 50,0 & 5 & 31,3 \\
\hline$(<50 \%)$ & 7 & 43.8 & 5 & 31.3 & 6 & 37.5 & 8 & 50.0 \\
\hline \multicolumn{9}{|l|}{ Partial } \\
\hline$(\leq 50 \geq 75 \%)$ & 8 & 50.0 & 10 & 62.3 & 8 & 50.0 & 5 & 31.3 \\
\hline Total $(<75 \%)$ & 1 & 6.2 & 1 & 6.2 & 2 & 12.5 & 3 & 18.8 \\
\hline \multicolumn{9}{|l|}{ Healing of the defect } \\
\hline Total & 9 & 56.3 & 5 & 31.3 & 6 & 37.5 & 9 & 56.3 \\
\hline Partial & 0 & 0.0 & 0 & 0.0 & 0 & 0.0 & 0 & 0.0 \\
\hline$<100 \% \geq 75 \%$ & 2 & 12.5 & 4 & 25.0 & 3 & 18.8 & 2 & 12.5 \\
\hline$<75 \% \geq 50 \%$ & 1 & 6.2 & 2 & 12.5 & 5 & 31.3 & 3 & 18.8 \\
\hline$<50 \% \geq 25 \%$ & 0 & 0.0 & 1 & 6.3 & 2 & 12.5 & 2 & 12.5 \\
\hline$<25 \%$ to $0 \%$ & 4 & 25.0 & 4 & 25.0 & 0 & 0.0 & 0 & 0.0 \\
\hline
\end{tabular}

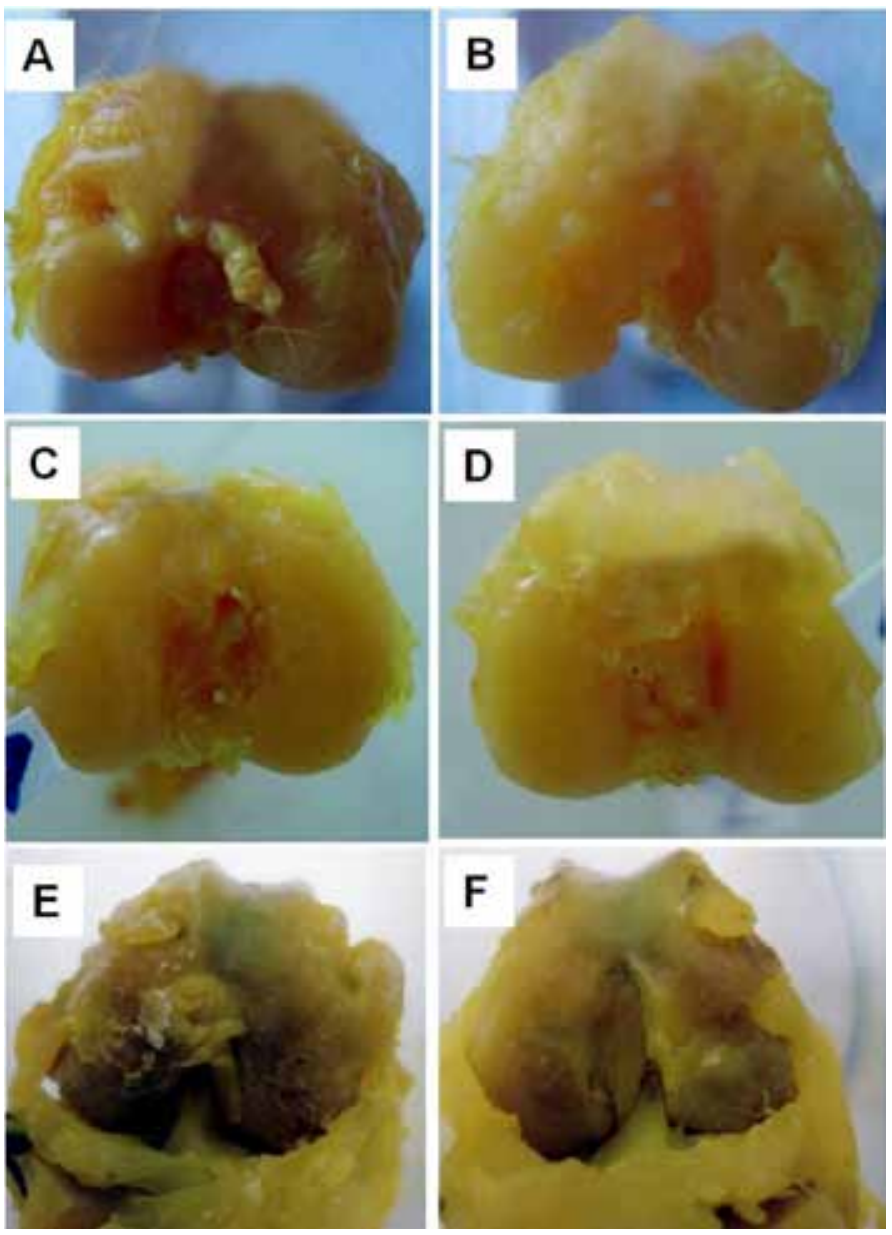

Figure 2 - Photograph of the right and left knees: (A and B) 90 days after surgery; $(C$ and $D) 120$ days after surgery; $(E$ and $F) 180$ days after surgery.

a diameter of $3.2 \times 4.0 \mathrm{~mm}$, in animals weighing 2 to $3 \mathrm{~kg}$, since this would be compatible with the size of the rabbits' knees ${ }^{(13-17)}$.

Among the surgical techniques so far used for filling in osteochondral lesions, no technique of proven efficiency has yet been found ${ }^{(6,13,16,24-26)}$. This is mainly due to the difficulties in achieving integration with hyaline cartilage, which has still not been reproduced artificially.

Techniques for stimulating the osteochondral tissue, such as perforations, abrasion, debridement and microfractures, promote excessive proliferation of fibroblasts, which results in formation of tissue known as fibrocartilage, with lower resistance than shown by the original hyaline cartilage $\mathrm{e}^{(10-15)}$.

Tissue transplantation to cover osteochondral defects, such as periosteal and perichondrial tissue, which is rich in mesenchymal cells, also does not induce differentiation of these cells in chondrocytes $^{(1,7,16,24,26)}$. 
Transplantation of cartilaginous and mesenchymal cells at different stages of differentiation has been studied in various models, but histological analysis has not shown the presence of hyaline cartilage. Although the initial results have been encouraging, other studies are needed in order to confirm whether or not this cartilage is present ${ }^{(1,7,9,12,16,24-33)}$.

Osteochondral transplantation techniques, carried out by means of removing osteochondral blocks from autologous or heterologous donor areas, have not regenerated the cartilage ${ }^{(12,16,24,27-33)}$. These techniques are mainly used in cases of traumatic lesions, with satisfactory results ${ }^{(28-33)}$.

Use of artificial materials such as polyglycolic acid, fibrin glue, collagen gel and carbon blocks, with the aim of filling osteochondral defects, has already been described. However, this has been seen to produce a severe inflammatory reaction $^{(3,4,8,12,18,25,33-35)}$. Use of this type of material, in association with culturing of mesenchymal cells in order to boost their growth potential, seems to be the future of new advances ${ }^{(1,7,8,12,24,32-35)}$.

Sugarcane biopolymer has already been used experimentally as a substitute for other tissues, in a support device for urinary incontinence ${ }^{(36)}$, as a replacement for vascular prostheses ${ }^{(23,37)}$, as a coadjuvant in wound healing ${ }^{(20)}$, as a replacement for the tympanic membrane ${ }^{(22)}$, in repairs to the dura mater ${ }^{(38)}$ and in bladder tissue ${ }^{(39)}$. Because these studies have shown that this biopolymer presents low cytotoxicity to these tissues, along with biocompatibility and integration, it was decided to apply this it to filling osteochondral defects in femoral condyles, and also because there would be no need to remove autografts.

\section{REFERENCES}

1. Amiel D, Coutts RD, Abel M, Stewart W, Harwood F, Akeson WH, et al. Rib perichondrial grafts for the repair of full-thickness articular-cartilage defects. J Bone Joint Surg Am. 1985;67(6):911-20.

2. Butinariu-Ephrat M, Robinson D, Mendes DG, Halpern N, Nevo Z. Resurfacing of goat articular cartilage by chondrocytes derived from bone marrow. Clin Orthop Relat Res. 1996;(330):234-43.

3. Buckwalter JA, Mankin HJ. Articular cartilage Part I: tissue design and chondrocyte-matrix interactions. J Bone Joint Surg. 1997;79(4):600-11.

4. Costa AJ, Oliveira CR, Leopizzi N, Amatuzzi MM. O uso da matriz óssea desmineralizada na reparação de lesões osteocondrais. Estudo experimental em coelhos. Acta Ortop Bras. 2001;9(4):27-38.
The chi-square test was used because comparisons were being made between the groups using qualitative variables $^{(40)}$.

In comparing the study and control groups of our study, we observed that the distribution among the variables of surface, coloration, consistency and healing of the defect was homogenous, without rejecting the initial hypothesis of nullity. The same was observed by Ribeiro et $a l^{(7)}$, who used the same experimental model but repaired the defects by means of grafts removed from the other knee. They also did not observe any differences in macroscopic quality between the groups.

Although the results from using sugarcane biopolymer gel for filling the osteochondral defects did not demonstrate any significant differences between the variables studied, it was observed that a planar surface was found more frequently in the animals in the study group. According to Amiel et $a l^{(1)}$, this is an important characteristic for determining that the osteochondral repair is considered biologically acceptable. On the other hand, this was not fully proven, perhaps because of the small number of rabbits studied.

\section{CONCLUSION}

It was concluded from macroscopic examination that, in osteochondral tissue repaired using sugarcane biopolymer gel, the joint surface, healing, coloration, consistency and continuity were similar to what was seen in the tissue formed in naturally healed osteochondral defects, in the control group. Given that this biomaterial is biocompatible, new studies on induced healing might prove its efficacy for reducing the time taken to achieve healing, in repairing joint cartilage defects.

5. Inouye CM, Fagundes DJ, Faloppa F, Novo NF, Juliano Y, Figueiredo AS. et al. Estudo morfológico da articulação do joelho de coelhos após a reparação de um efeito osteocondral. Acta Cir Bras. 2002;17(Suppl 1):403-9.

6. Steadman JR, Rodkey WG, Briggs KK. Microfraure to treat full-thickness chondral defects: surgical technique, rehabilitation, and outcomes. J Knee Surg. 2002;15(3):170-6.

7. Ribeiro JL, Camanho GL, Takita LC. Estudo macroscópico e histológico de reparos osteocondrais biologicamente aceitáveis. Acta Ortop Bras. 2004;12(1):16-21.

8. Sassioto MCP, Cardoso Filho N, Facco GG, Sodrés ST, Neves N, Purisco SU. Efeito da Casearia sylvestris no reparo ósseo com matriz óssea bovina desvitalizada em ratos. Acta Cir Bras. 2004;19(6):637-41. 
9. Peterson L. Autologous chondrocyte transplantation: 2-10 year follow-up in 219 patients. In: Proceedings of the $65^{\text {th }}$ Annual Meeting of the American Academy of Orthopaedic Surgeons. New Orleans: Am Acad Orthop Surg; 1998.

10. O'Driscoll SW. The healing and regenerating of articular cartilage. J Bone Joint Surg Am. 1998;80(12):1795-812.

11. Moseley JB, Felson DT, Buckwalte J. Debridement and lavage for osteoarthritis of knee. N Eng J Med. 2002;347(11):81-8.

12. Cherubino P, Grassi FA, Bulgheroni, P, Ronga M. Authologous chondrocyte implantation using a bilayer collagen membrane: preliminary report. J Orthop Surg. 2003;11(1):10-5.

13. Hangody $\mathrm{L}$. The mosaicplasty technique for osteochondral lesions of the talus. Foot Ankle Clin. 2003;85(1):259-73.

14. Yasuaki N, Koji M, Kobayashi M, Suzuki T, Kuroki H, Ikeuchi K, Nakamura T. Assessment of mechanical properties of articular cartilage after mosaicplasty in second-look arthroscopy. Arthroscopy, 2005;30(1): 47-51.

15. Bartha L, Vajda A, Duska Z, Rahmeh H, Hangody L. Autologous osteochondral mosaicplasty grafting. J Orthop Sports Phys Ther. 2006;36(10):739-50.

16. Wahegaonkar AL, Doi K, Hattori Y, Addosooki A. Technique of osteochondral autograft transplantation mosaicplasty for capitellar osteochondritis dissecans. J Hand Surg. 2007;32(9):1454-61.

17. Haasper C, Zelle BA, Knobloch K. No mid-term difference in mosaicplasty in previously treated versus previously untreated patients with osteochondral lesions of the talus. Arch Orthop Trauma Surg. 2008;128(5):499-504.

18. Paterson-Beedle M, Knenedy JF, Melo FA, Lloyd LL, MedeirosV. A cellulosic exopolysaccharide produced from sugarcane molasses by a Zoogloea $\mathrm{sp}$. Carbohydrate. Polymers. 2000;42:375-83.

19. Coelho MC, Carrazoni PG, Monteiro VL, Melo FA, Mota R, Tenório Filho F. Biopolímero produzido a partir de cana de açúcar para cicatrização cutânea. Acta Cir Bras. 2002;17(Suppl 1):1-7.

20. Castro C, Aguiar J, Melo F, Silva W, Marques E, Silva D. Citotoxicidade de biopolímero de cana-de-açúcar. An Fac Med Univ Fed Pernamb. 2004;49(2):119-23

21. Lima F, Lima J, Hirakawa $P$, Medeiros Júnior D, Lima F, Aguiar J. Resposta inflamatória a membranas de biopolímero de cana-de-açúcar e telas de polipropileno re-implantadas no peritôneo parietal de ratos. An Fac Med Univ Fed Pernamb. 2005;50(1):37-40.

22. Silva D, Aguiar J, Marques A, Coelho A, Rolim Filho E. Miringoplastia com enxerto livre de membrana de biopolímero de cana-de-açúcar e fascia autóloga em Chinchilla laniger. An Fac Med Univ Fed Pernamb. 2006;51(1):45-51.

23. Aguiar J, Lins E, Marques S, Coelho A, Rossiter R, Melo R. Sugarcane biopolymer patch in femoral artery angioplasty in dogs. Acta Cir Bras. 2007;22(Suppl.1):77-81.

24. BlueCross BlueShield Association (BCBSA), Technology Evaluation Center (TEC). Autologous chondrocyte transplantation of the knee. TEC Assessment Program. Chicago IL: BCBSA; June 2003; 18. Disponível em: http://www.bcbs. com/tec/vol18/18_02.html. Acesso em 15 de setembro, 2004.

25. Karataglis D, Learmonth DJ. Management of big osteochondral defects of the knee using osteochondral allografts with the MEGA-OATS technique. Knee. 2005;12(5):389-93
26. Hangody L, Vásárhelyi G, Hangody LR, Sukosd Z, Tibav G, Bartha L. Autologous osteochondral grafting-- technique and long-term results. Injury. 2008;39(Suppl 1):S32-S39.

27. Horas U, Pelinkovic D, Herr G, Aignet T, Schnettler R. Autologous chondrocyte implantation and osteochondral cylinder transplantation in cartilage repair of the knee joint. A prospective, comparative trial. J Bone Joint Surg Am. 2003;85(2):185-192.

28. Dozin B, Malpeli M, Cancedda R, Bruzzi P, Calcagno S, Molfetta L, et al. Comparative evaluation of autologous chondrocyte implantation and mosaicplasty: A multicentered randomized clinical trial. Clin J Sport Med. 2005;15(4):220-6.

29. Goomer RS, Amiel D. Repair of articular cartilage defects by ex-vivo gene therapy. Curr Opin Orthop. 2000;11(5):378-82.

30. Cain EL, Clancy WG. Treatment algorithm for osteochondral injuries of the knee. Clin Sports Med. 2001;20(2):321-42.

31. Lieberman JR, Daluiski A, Einhorn TA. The role of growth factors in the repair of bone. Biology and clinical applications. J Bone Joint Surg Am. 2002;84(6):1032-44.

32. Melo F. Contribuição ao estudo cinético da produção de polissacarídeos extracelulares por Zoogloea sp. em melaço de cana-de-açúcar [dissertação]. Recife: Universidade Federal de Pernambuco; 2003.

33. Hayashi K, Kubo T, Doi K, Tabata Y, Akagawa Y. Development of new drug delivery system for implant bone augmentation using a basic fibroblast growth factor-gelatin hydrogel complex. Dent Mater J. 2007;(2692):170-7.

34. lamaguti LS, Brandão CVS, Minto BW, Mamprim MJ, Ranzani JJT, Gomes DC. Utilização de membrana biossintética de celulose na trocleoplastia experimental em cães. Avaliação clínica, radiográfica e macroscópica. Vet Zootec. 2008;15(1):160-8.

35. Akagawa Y, Kubo T, Koretake K, Hayashi K, Doi K, Matsuura A, et al. Initial bone regeneration around fenestrated implants in Beagle dogs using basic fibroblast growth factor-gelatin hydrogel complex with varying biodegradation rates. J Prosthodont Res 2009;53(1):41-7.

36. Lucena RG. Utilização do biopolímero de cana-de-açúcar como novo material para sling pubo vaginal: análise estereológica [tese]. Recife: Universidade Federal de Pernambuco; 2007.

37. Marques S. Um novo substituto vascular: estudo experimental com biopolímero de cana-de-açúcar [livre docência]. Recife: Universidade Federal de Pernambuco; 2006.

38. Lima FM. Membrana de biopolímero de cana-de-açúcar como substituto de dura-máter em ratos Wistar [tese]. Recife: Universidade Federal de Pernambuco; 2008.

39. Lima SV, Aguiar JL, Castro CM, Vilar FO, Carvalho B, Souza Júnior E, et al. Reepithelialized bowel segment for bladder augmentation: a pilot study in an animal model. [Inter Braz J Urol. 2006;32(Suppl.1):89]. XXVIII Congresso de la Confederacion Americana de Urologia - CAU 2006, Recife.

40. Arango HG. Bioestatística: teórica e computacional. 2a. ed. Rio de Janeiro: Guanabara Koogan; 2005. 